\title{
An Experimental Study on the Characteristics of Compartment Fires in Relation to Opening Size
}

\author{
Oh-Sang Kweon ${ }^{1}$, Heung-Youl Kim ${ }^{1}$ and Seung-Cho Yang ${ }^{2 *}$ \\ 1. Fire Research Institute, Korea Institute of Civil Engineering and Building Technology, HwaSeong Si, KS009, Republic of Korea \\ 2. Architectural Engineering, Hannam University, Daejeon, KS015, Republic of Korea
}

\begin{abstract}
The incipient stage of a compartment fire is fuel controlled, which means being affected by the amount and configuration of combustibles. This study is to estimate the characteristics of compartment fires in relation to opening sizes, full-scale combustion experiments were conducted in a $2.4(\mathrm{~L}) \mathrm{m} \times 3.6(\mathrm{~W}) \mathrm{m} \times 2.4(\mathrm{H}) \mathrm{m}$ compartment having an opening which was $0.8(\mathrm{~L}) \mathrm{m} \times 2.0(\mathrm{H}) \mathrm{m}$ and $0.8(\mathrm{~L}) \mathrm{m} \times 1.0(\mathrm{H}) \mathrm{m}$. The results of the experiments and estimations made by the methods suggested in existing studies were compared to analyze the influence of ventilation characteristics. Maximum heat release rate from burner A was $443.08 \mathrm{~kW}$ observed at 57 second point when the height of the opening was $2.0 \mathrm{~m}$ and $344.57 \mathrm{~kW}$ at 99 second point when opening height was $1.0 \mathrm{~m}$. Maximum heat release rate from burner B was $260.26 \mathrm{~kW}$ observed at 84 second point and $188.04 \mathrm{~kW}$ at 117 second point when the height of the opening was $2.0 \mathrm{~m}$ and $1.0 \mathrm{~m}$, respectively. Maximum heat release rates from both burner A and B were higher and observed faster when the height of the opening was $2.0 \mathrm{~m}$. The values of heat release rate calculated by the method of Babrauskas. The values obtained by the Method of MQH were the closest approximations to the combustion experiment results due to the application of appropriate ventilation factors.
\end{abstract}

Key words: Ventilation factor, compartment, Fire, combustion experiment, performance based design.

\section{Introduction}

Performance-based fire safety design is widely used along with existing laws, and fire safety codes and guidelines are provided in many countries. Fire safety in a building starts with the analysis of fire risk, which requires the estimation of fire growth characteristic. A fire in a building evolves in the order of ignition $\rightarrow$ growth $\rightarrow$ flashover $\rightarrow$ burning $\rightarrow$ decay. Fire behavior varies depending on compartment size, ventilation condition and the amount and configuration of combustibles. Burning rate in a ventilation-controlled compartment fire is decided by the amount of air inflow through openings as Kawagoe [1] suggested.

Fire behavior in a compartment is represented by heat release rate and temperature change [2], and ventilation-controlled fires are affected by the presence/absence and size of openings. Design Fires

\footnotetext{
*Corresponding author: Seung Cho Yang, Ph.D. candidate, research fields: architectural and fire engineering.
}

are usually used to estimate the behavior of compartment fires, and fire growth curves estimated through the Design Fires are uses as input data for fire behavior estimation programs such as FDS (Fire dynamics simulator) [3]. The estimation of fire behavior in a compartment is based on the assumption that the amount of smoke emission to outside is almost equal to the amount of air inflow. Therefore, opening size affects the behavior of a compartment fire [4]. One of the methods to estimate fire behavior is to check whether flashover occurs in a compartment or not. Flashover signals the spread of flames to the whole compartment. The NFPA 265 [5] defines flashover as a situation that involves heat release rate exceeding $1 \mathrm{MW}$, heat flux at a floor exceeding $20 \mathrm{~kW} / \mathrm{m}^{2}$, average temperature at the lay of smoke exceeding $600{ }^{\circ} \mathrm{C}$ or the outflow of fames through openings. Fire growth before flashover is usually limited by thermal decomposition rate, while is limited by ventilation because the amount of thermally 
decomposed fuel exceeds that of combustible fuel [6].

Heat release rates are calculated with ventilation conditions in a compartment taken into consideration to decide the presence/absence of flashover. This method of calculating heat release rates, which is based on mass-energy balance in a single compartment with a single opening, does not reflect various configurations of compartments or lack of ventilation [7]. Since the estimation of fire behavior requires considering various factors such as compartment size, the influence of openings and the configuration and amount of combustibles, method using ventilation factor has limit. However, it is an easy and fast way of estimation.

In this study, full-scale combustion experiments were conducted using heptane pool burners in a $2.4(\mathrm{~L})$ $\mathrm{m} \times 3.6(\mathrm{~W}) \mathrm{m} \times 2.4(\mathrm{H}) \mathrm{m}$ compartment having a single opening which was $0.8(\mathrm{~L}) \mathrm{m} \times 2.0(\mathrm{H}) \mathrm{m}$ in size to estimate the characteristics of compartment fires in relation to opening size. Heat release rates associated with different opening sizes were measured and the influence of ventilation conditions suggested in existing studies was analyzed.

\section{Full-Scale Combustion Experiment}

The combustion experiments were conducted using a Room Corner Tester shown in Fig. 1 as suggested by the ISO 9705 [8]. RCT measures products of combustions such as oxygen, carbon monoxide and carbon dioxide and estimates heat release rates. Heat release rates are calculated by oxygen consumption rate method [9], which is based on the fact that net combustion energy is proportional to the amount of oxygen needed for combustion. It means that $13.1 \mathrm{MJ}$ are generated when $1 \mathrm{~kg}$ oxygen is consumed.

Eq. (1) is used to measure oxygen concentration in exhaust gas in RCT duct and Eq. (2) is for oxygen, carbon monoxide and carbon dioxide.

$$
\dot{Q}(t)=\left(\frac{\Delta h_{c}}{r_{0}}\right)(1.10) \mathrm{C} \sqrt{\frac{\Delta P}{T_{s}}} \frac{\left(X_{O_{2}^{0}}-X_{O_{2}}(t)\right)}{\left(1.105-1.5 X_{O_{2}}(t)\right)}
$$

$$
\dot{Q}(t)=1.10\left(\frac{\Delta h_{c}}{r_{0}}\right) X_{O_{2}^{0}}\left[\frac{\Phi-0.172(1-\Phi) \frac{X_{C O}}{X_{C O}}}{(1-\Phi)+1.105 \Phi}\right] \cdot \dot{m}_{e}
$$

In the equations, $\Delta\left(h_{c} / r_{0}\right)$ is $13.1 \mathrm{~kJ} / \mathrm{g}$ and $\mathrm{C}$ is calibration constant. $\Delta \mathrm{P}$ is pressure difference between orifice ends and $T_{e}$ is exhaust gas temperature. Superscript 0 means "before combustion". $\dot{m}_{e}=$ $C \sqrt{\frac{\Delta P}{T_{e}}}$ and $\Phi$ is defined as follows:

$$
\Phi=\frac{X_{O_{2}^{0}}\left(1-X_{C O_{2}}-X_{C O}\right)-X_{O_{2}}}{X_{O_{2}^{0}}\left(1-X_{C O_{2}}-X_{C O}-X_{O_{2}}\right)}
$$

Two burners which were $0.65(\mathrm{~L}) \mathrm{m} \times 0.65(\mathrm{~W}) \mathrm{m} \times$ $0.15(\mathrm{H}) \mathrm{m}($ BurnerA) and 0.46(L) $\mathrm{m} \times 0.46(\mathrm{~W}) \mathrm{m} \times$ $0.15(\mathrm{H}) \mathrm{m}$ (BurnerB) with 1 liter of heptane each were used in the combustion experiments. Opening height was set to be $1 \mathrm{~m}$ and $2 \mathrm{~m}$. The experiments were continued until the heptane was fully combusted and heat release rates were measured. Table 1 shows the scenario of the experiments.

\section{Full-Scale Experiment Results}

Heat release rates from the 2 burners (A and B) were measured when the height of the opening was $2.0 \mathrm{~m}$ and $1.0 \mathrm{~m}$ to observe the change associated with opening size. Fig. 2 shows the experiments. Conducted until the full combustion of heptane, all of the experiments were terminated within 4 minutes.

Fig. 3 shows heat release rates measured at the experiments. Changes in heat release rate started 30

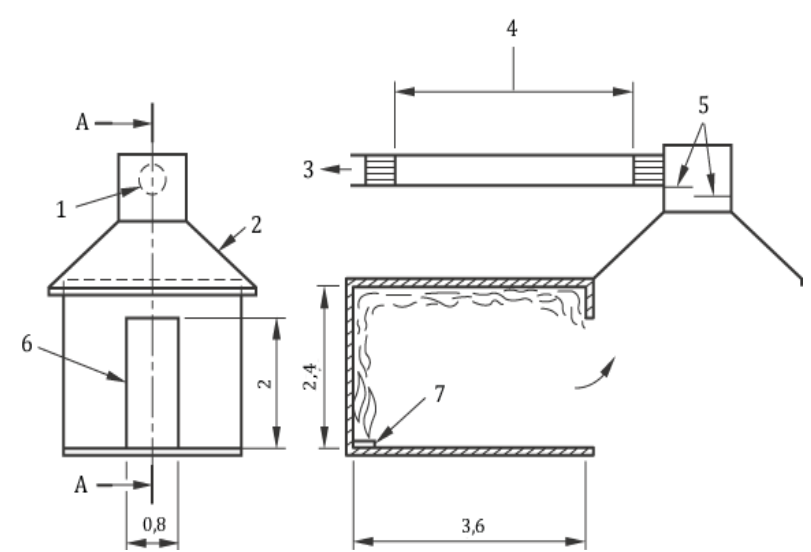

Fig. 1 Room Corner Tester: (1) exhaust duct $(\varnothing 0.4)$ (2) hood $\left(3 \times 3 \mathrm{~m}^{2}\right)(3)$ to exhaust gas cleaning (4) length $5 \mathrm{~m} \mathrm{(5)}$ baffles (6) doorway. 
Table 1 Scenario of combustion experiments.

\begin{tabular}{|c|c|c|c|c|c|}
\hline Compartment size & $\begin{array}{l}\text { Opening } \\
\text { size(compartment) }\end{array}$ & $\begin{array}{l}\text { Opening } \\
\text { size(experiment) }\end{array}$ & Burner size & $\begin{array}{l}\text { Burner } \\
\text { source }\end{array}$ & Measurement \\
\hline $\begin{array}{l}2.4(\mathrm{~L}) \times 3.6(\mathrm{~W}) \times \\
2.4(\mathrm{H}) \mathrm{m}^{3}\end{array}$ & $0.8(\mathrm{~L}) \times 2.0(\mathrm{H}) \mathrm{m}^{2}$ & $\begin{array}{l}0.8(\mathrm{~L}) \times 2.0(\mathrm{H}) \\
\mathrm{m}^{2} \\
0.8(\mathrm{~L}) \times 1.0(\mathrm{H}) \\
\mathrm{m}^{2}\end{array}$ & $\begin{array}{l}\text { Burner A: } 0.65(\mathrm{~L}) \times 0.65(\mathrm{~W}) \times 0.15(\mathrm{H}) \mathrm{m}^{3} \\
\text { Burner B: } 0.46(\mathrm{~L}) \times 0.46(\mathrm{~W}) \times 0.15(\mathrm{H}) \mathrm{m}^{3}\end{array}$ & $\begin{array}{l}\text { Heptane } \\
(1.0 \mathrm{~L})\end{array}$ & Heat release rate \\
\hline
\end{tabular}

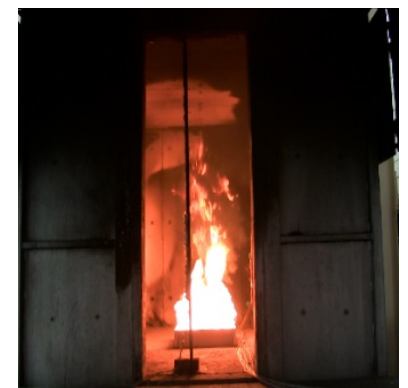

(a)

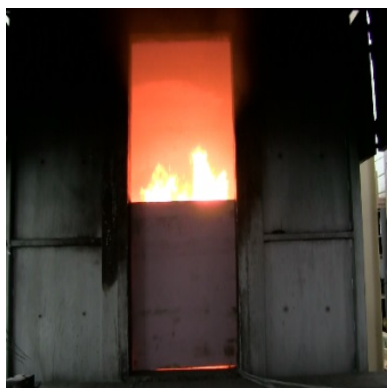

(b)

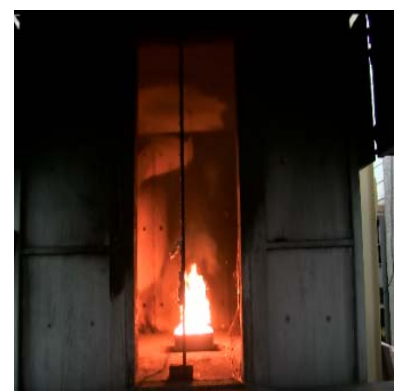

(c)

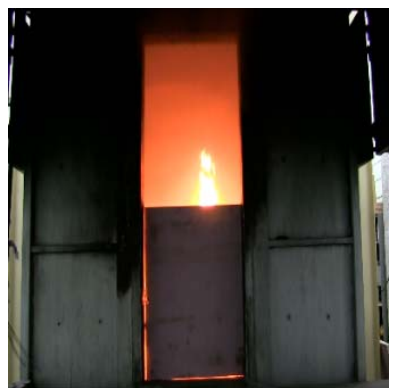

(d)

Fig. 2 Combustion experiment photos (a) Burner A 2.0(H), (b) Burner A 1.0(H), (c) Burner B 2.0(H), (d) Burner B 1.0(H).
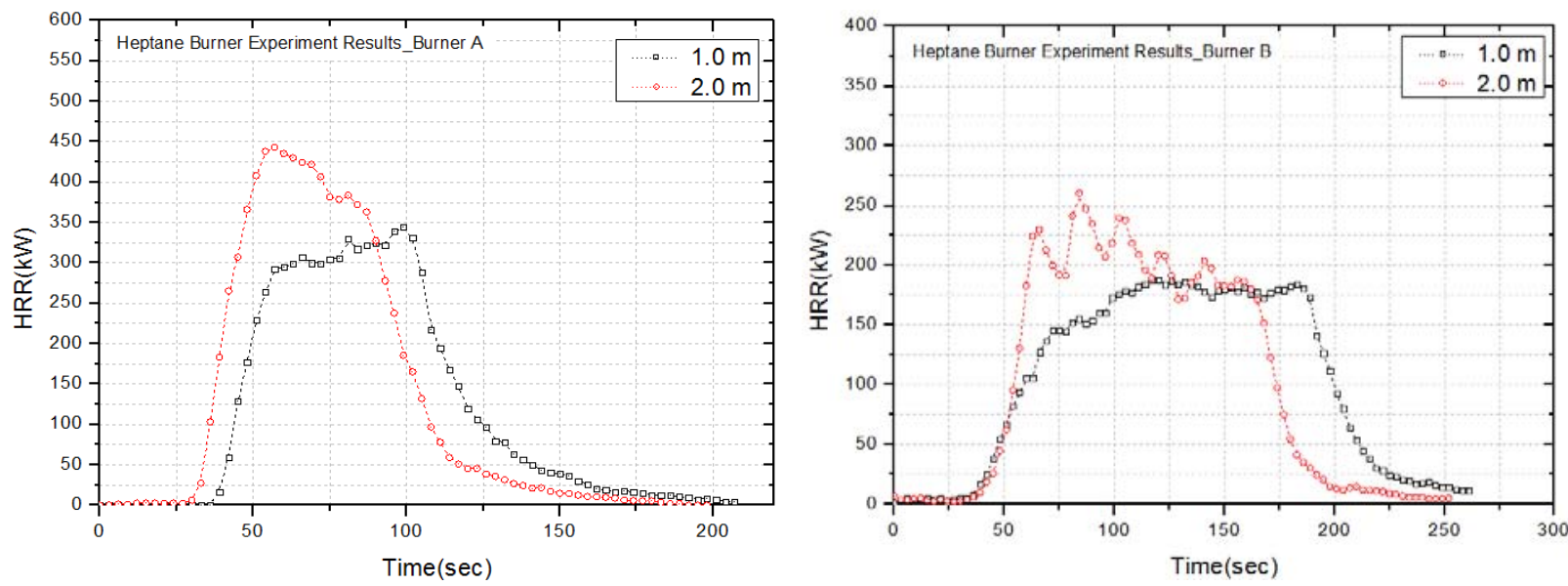

Fig. 3 Results of combustion experiments (a) Burner A, (b) Burner B.

Table 2 The Max. HRR \& Time.

\begin{tabular}{llll}
\hline Burner type & Opening size & Max. HRR $(\mathrm{kW})$ & Time $(\mathrm{sec})$ \\
\hline \multirow{2}{*}{ Burner A } & $2.0(\mathrm{H}) \mathrm{m}$ & 443.08 & 57 \\
& $1.0(\mathrm{H}) \mathrm{m}$ & 344.57 & 99 \\
\hline \multirow{2}{*}{ Burner B } & $2.0(\mathrm{H}) \mathrm{m}$ & 260.26 & 84 \\
& $1.0(\mathrm{H}) \mathrm{m}$ & 188.04 & 117 \\
\hline
\end{tabular}

seconds after ignition. Maximum heat release rates from a burner varied depending on opening size. Table 2 shows the maximum heat release rates and the time taken to reach the maximum values.

In burner $A$, the maximum heat release rate of $443.08 \mathrm{~kW}$ was measured 57 seconds after ignition when opening height was $2.0 \mathrm{~m}$. The maximum heat release rate was $344.57 \mathrm{~kW}$ measured at 99 second point when opening height was $1.0 \mathrm{~m}$. In burner $\mathrm{B}$, the maximum heat release rate of $269.26 \mathrm{~kW}$ was measured at 84 second point when opening height was $2.0 \mathrm{~m}$. The maximum heat release rate was $188.04 \mathrm{~kW}$ at 117 second point when opening height was $1.0 \mathrm{~m}$. In both burners, the maximum heat release rates were higher and observed earlier when opening height was $2.0 \mathrm{~m}$. 


\section{Influence of Ventilation Factor}

Changes in temperature and heat release rate were estimated to identify the characteristics of compartment fires. Table 3 summarizes the methods provided by the SFPE (10). $A_{V} \sqrt{h_{v}}$ is ventilation factor based on the area and height of ventilation opening. Although the amount and arrangement of combustibles also affect the behavior of a compartment fire, ventilation factor exerts the greatest influence if the fire is ventilation controlled. In order to analyze the influence of ventilation factors, the results of the full-scale combustion experiments were compared with the values calculated by the methods suggested in existing studies.

Table 4 shows the parameters used for the estimation of heat release rates in compartment fires. The values of parameters identical to those in the combustion experiments were used in the estimations. The compartment was $2.4(\mathrm{~L}) \mathrm{m} \times 3.6(\mathrm{~W}) \mathrm{m} \times 2.4(\mathrm{H}) \mathrm{m}$ and the ventilation openings were $0.8 \mathrm{~m}$ in width and $2.0 \mathrm{~m}$ and $1.0 \mathrm{~m}$ in height. Therefore, the areas of ventilation openings were $1.60 \mathrm{~m}^{2}$ and $0.80 \mathrm{~m}^{2}$ and those of the compartment excluding ventilation opening were $44.45 \mathrm{~m}^{2}$ and $45.25 \mathrm{~m}^{2}$.

Effective heat transfer coefficient of 0.007 $\mathrm{kW} / \mathrm{m}^{2} \cdot \mathrm{K}$ was used to take into consideration the interior finishing of the compartment with fireproofing bricks.
The method of Babrauskas provided the highest values of heat release rate and the values obtained by the method of MQH showed the closest approximation to those measured at Burner A. These results are deemed attributable to the fact that the methods of Babrauskas and Thomas use compartment size and ventilation factor only, while the method of $\mathrm{MQH}$ considers the features of compartment surfaces, too.

The values of heat release rate obtained by the method of Babrauskas reflect the greatest influence of ventilation factors and those by the method of $\mathrm{MQH}$ were the closest to the combustion experiment results due to appropriate ventilation factors.

The IFEG (International Fire Engineering Guidelines) (11) based on the analysis of performance-based fire safety design methods provided by NRC (National Research Council of Canada), ICC (International Code Council), DBH (Department of Building and Housing) and ABCB (Australian Building Codes Board) and BS 7974, British performance-based design method suggest how to decide flashover and estimate heat release rates as shown in Table 6.

The IFEG and BS 7974 provide similar criteria for flashover in a compartment. The IFEG suggests hot gas temperature of $600{ }^{\circ} \mathrm{C}$ at the upper part of a compartment or radiant heat flux of $20 \mathrm{~kW} / \mathrm{m}^{2}$ at a floor

Table 3 Methods for predicting flashover HRR.

\begin{tabular}{ll}
\hline MQH & $Q_{F O}=610\left(h_{k} A_{T} A_{v} \sqrt{h_{v}}\right)^{1 / 2}$ \\
\hline McCaffrey, Quintiere and Harkleroad) & $Q_{F O}=750 A_{v}\left(\sqrt{h_{v}}\right)$ \\
\hline Babrauskas & $Q_{F O}=7.8 A_{T}+378 A_{v}\left(\sqrt{h_{v}}\right)$ \\
\hline$A_{T}\left(m^{2}\right):$ Total area of the compartment excluding area of vent openings \\
$A_{v}\left(m^{2}\right):$ Area of ventilation opening \\
$h_{v}(m):$ Height of ventilation opening \\
$h_{k}\left(\mathrm{~kW} / \mathrm{m}^{2} \cdot \mathrm{K}\right):$ Effective heat transfer coefficient \\
\hline
\end{tabular}

Table 4 Parameters in HRR estimation.

\begin{tabular}{lll}
\hline Parameters & $h_{v}=2.0 \mathrm{~m}$ & $h_{v}=1.0 \mathrm{~m}$ \\
\hline$A_{T}\left(\mathrm{~m}^{2}\right)$ & 44.45 & 45.25 \\
$A_{v}\left(\mathrm{~m}^{2}\right)$ & 1.60 & 0.80 \\
$h_{v}(m)$ & 2.26 & 0.8 \\
$h_{k}\left(\mathrm{~kW} / \mathrm{m}^{2} \cdot \mathrm{K}\right)$ & 0.007 & \\
\hline
\end{tabular}


Table 5 Influence of ventilation factor.

\begin{tabular}{|c|c|c|c|c|c|c|}
\hline \multirow{3}{*}{ Methods } & & \multicolumn{3}{|c|}{ Data $[\mathrm{kW}]$} & \multicolumn{2}{|c|}{$\mathrm{Data} / A_{v} \sqrt{h_{v}}[\mathrm{~kW}]$} \\
\hline & & \multicolumn{4}{|c|}{$A_{v} \sqrt{h_{v}}$} & \\
\hline & & 2.26 & 0.80 & 2.26 & 0.80 & \\
\hline $\mathrm{MQH}$ & & 521.93 & 313.12 & 230.94 & 391.40 & 160.46 \\
\hline Babrauskas & & 1693.39 & 598.70 & 749.29 & 748.38 & 0.91 \\
\hline Thomas & & 1200.18 & 654.69 & 531.05 & 818.36 & 287.31 \\
\hline \multirow{2}{*}{ Experiment } & Burner A & 443.08 & 344.57 & 196.05 & 430.71 & 234.66 \\
\hline & Burner B & 260.26 & 188.04 & 115.16 & 235.05 & 119.89 \\
\hline
\end{tabular}

Table 6 Prediction of HRR.

\begin{tabular}{lll}
\hline & IFEG & BS 7974-1 \\
\hline & $\begin{array}{l}\text { Hot gas layer temperature of } 600{ }^{\circ} \mathrm{C} \text { in a compartment } \\
\text { Radiant heat flux of } 20 \mathrm{~kW} / \mathrm{m}^{2} \text { at a compartment floor }\end{array}$ & $\begin{array}{l}\text { Hot gas layer temperature of } 550 \sim 600{ }^{\circ} \mathrm{C} \text { in a } \\
\text { compartment }\end{array}$ \\
& $\begin{array}{l}\text { Consumption of } 80 \% \text { of fuel signals the decay of a } \\
\text { compartment fire. }\end{array}$ & $\begin{array}{l}\text { Consumption of } 80 \% \text { of fuel signals the decay of a } \\
\text { compartment fire. }\end{array}$ \\
$\begin{array}{ll}\text { Heat release rate at at } \\
\text { flashover }\end{array}$ & $\begin{array}{l}\text { Equation suggested by Kawagoe and Sekine } \\
\text { Equation suggested by Walton \& Thomas }(2002)\end{array}$ \\
\hline
\end{tabular}

as the signal for flashover. BS 7974 suggests hot gas temperature of $550-600{ }^{\circ} \mathrm{C}$. Both consider the consumption of $80 \%$ of combustibles as the beginning of fire decay. The IFEG suggests the equation of Thomas (1981) for heat release rate and BS 7974 suggests that of Walton \& Thomas (2002).

\section{Conclusions}

While the estimation of fire configuration is indispensable in establishing fire prevention measures for buildings, various factors such as compartment size, opening size and the amount and arrangement of combustibles impose difficulties on the estimation. A fire in a compartment grows rapidly as it changes from a fuel-controlled fire at its early stage characterized by the influence of combustibles to a ventilation-controlled fire characterized by the influence of openings. Ventilation factor $\left(A_{v} \sqrt{h_{v}}\right)$ decided by opening area and height is the major factor when a fire is fuel controlled. In this study, heat release rates measured at full-scale combustion experiments were compared with the values obtained by estimation methods suggested by existing studies in order to evaluate the influence of ventilation factors. The combustion experiments were conducted in a $2.4(\mathrm{~L}) \mathrm{m} \times 3.6(\mathrm{~W}) \mathrm{m} \times 2.4(\mathrm{H}) \mathrm{m}$ compartment using 2 heptane pool burners which were $0.65(\mathrm{~L}) \mathrm{m} \times$ $0.65(\mathrm{~W}) \mathrm{m} \times 0.15(\mathrm{H}) \mathrm{m}($ BurnerA) and $0.46(\mathrm{~L}) \mathrm{m} \times$ $0.46(\mathrm{~W}) \mathrm{m} \times 0.15(\mathrm{H}) \mathrm{m}($ BurnerB) in dimensions. The area of ventilation opening was set to be $0.8(\mathrm{~L}) \mathrm{m} \times$ $2.0(\mathrm{H}) \mathrm{m}$ and $0.8(\mathrm{~L}) \mathrm{m} \times 1.0(\mathrm{H}) \mathrm{m}$. The methods of $\mathrm{MQH}$, Babrauskas and Thomas were used for the estimation of heat release rates.

Higher ventilation factor resulted in higher heat release rates in the experiments and estimations and maximum heat release rates were reached faster when the factor was higher. The values calculated by the method of MQH showed similarity to those measured at Burner A, seemingly because only compartment size and ventilation factor are used in the methods of Babrauskas and Thomas, while the method of $\mathrm{MQH}$ takes the features of compartment surfaces into consideration. Heat release rates calculated by the method of Babrauskas showed the greatest influence of ventilation factors and those calculated by the method of MQH were close to the combustion experiment results due to the application of appropriate ventilation factors.

\section{Acknowledgments}

This research was supported by a grant (16AUDP-B100356-02) from urban architecture 
research program funded by the Ministry of Land, Infrastructure and Transport of Korean government.

\section{References}

[1] Kawagoe, K. 1958. Fire Behavior in Room - Report. Building Research Institute, Tokyo, No. 27.

[2] Barnett, C. R. 1998. "Design Fires for Structural Engineers." IPENZ Transactions 25 (1): 47-58.

[3] Kweon, O. S. 2014. "A Study on the Prediction of Temperature Curve by Compartment Fire Experiment." Fire Science and Engineering 28 (5): 44-51.

[4] Quintiere, J. G. 1998. "Principles of Fire Behavior." Delmar Publishers.

[5] NFPA 265. 2002. Standard Methods of Fire Tests for Evaluating Room Fire Growth Contribution of Textile Coverings on Full Height Panels and Walls.
[6] Buchanan, A. H. 2001."Fire Engineering Design Guide.” University of Canterbury.

[7] Peacock, R. D., Reneke, P. A., Bukowski, R. W. and Babrauskas, V. 2014. "Defining Flashover for fire Hazard Calculations." Fire Safety Journal 32: 331-45.

[8] ISO 9705-1. Reaction to Fire Tests-Room Corner Test for Wall and Ceiling Lining Products-Part1: Test Method for a Small Room Configuration.

[9] Babrauskas, V. and Grayson, S. J. 1992. Heat Release in Fires. Elsevier.

[10] SFPE. 2002. SFPE Handbook of Fire Protection Engineering. Edited by Philip J. DiNenno.

[11] NRC, ICC, DBH and ABCB. 2005. International Fire Engineering Guidelines.

[12] BSI. 2011. BS PD 7974: Application of Fire Safety Engineering Principles to the Design of Building. 